\title{
THE PROBLEM OF GLOBAL TURMOIL IN THE DILEMMA OF GLOBALIZATION-MULTILATERALISM: LONG-TERM INTERACTIONS BETWEEN DEMOCRACY AND ECONOMY WITHIN THE FRAMEWORK OF POLITICAL REGIMES*
}

\author{
Küreselleşme-Çok Taraflılık İkileminde Küresel Kargaşa Sorunu: Siyasi Rejimler Çerçevesinde \\ Demokrasi ve Ekonomi Arasındaki Uzun Vadeli Etkileşimler
}

\author{
Emin Ahmet KAPLAN ${ }^{1}$ Rana DAYIOĞLU ERUL²
}

\section{ÖZET}

Son zamanlarda küresel krizden bir kaçış noktası bulunamaması, çok taraflı kurumların artık kendilerinden beklenen işlevleri yerine getiremediğini göstermiştir. Bu bağlamda, demokratik ülkeler tarafından benimsenecek politikaların küresel kargaşa ve krizden kurtulmada gerekli olduğu düşünülmektedir. Küreselleşmeden kaynaklanan değişim ve gelişmelerin neden olduğu küresel kargaşadan kaçmada çok taraflılığın etkin rol oynaması gerektiği görüşüne rağmen çok taraflı kurumlar, küresel güç olmaya çalıșan ülkelerin politikaları, küresel sistem içinde meydana gelen istikrarsızlık ve küresel gelişmeleri algılamadaki yetersizlikleri nedeniyle temel işlevlerini yerine getirememektedir. $\mathrm{Bu}$, küresel kargaşadan kaçmak için çok taraflılığın yönlerinin küreselleşme çerçevesinde yeniden değerlendirilmesini gerektirmektedir. Bu nedenle çalışmanın amac1, bir hükümet içindeki siyasi rejim türlerinin veya demokrasinin önemi açısından kurumsal ve sosyoekonomik değişkenlerin ekonomik büyüme üzerindeki etkilerini ölçmektir. Bu doğrultuda 1984-2015 döneminde otoriter rejim ve tam demokrasi rejimleri çerçevesinde, siyasi rejimdeki 31 ülke, panel veri ekonometrik yöntemi ile analize dahil edilmiștir. Calışmada ekonomik büyümenin uzun vadeli kurumsal belirleyicileri siyasi rejim türleri açısından incelenmiş ve analizin sonuçlarına göre gelișmiş ülkelerden oluşan tam demokrasi rejimi grubundaki sosyoekonomik değişkenlerin ekonomik büyümeyi teşvik ettiği gözlemlenmiștir. Bu sonuçlar, bu gruptaki ülkelerin gelişmiş bir sosyal, kültürel ve ekonomik altyapıya sahip olmasından ileri gelmektedir. Sonuç olarak, bir çözüm üretmede etkisiz kalan çok taraflı kurumların son küresel gelişmeler bağlamında yeniden ele alınması gerektiği, bu değerlendirmelerin ülkelerin sosyo-kültürel altyapılarının geliştirilmesi ve demokratikleşme eğilimleri çerçevesinde yapılması gerektiği önem taşımaktadır.

Anahtar Kelimeler: Küreselleşme, küresel kargaşa, çok tarafll1ık, demokrasi ve ekonomik büyüme, politik rejimler.

\author{
ABSTRACT
}

Recent inabilities to find an escape point from the global crisis has demonstrated that multilateral institutions cannot fulfill the functions expected from them anymore. In this respect, the policies to be adopted by democratic countries are thought to be essential in the escape from global turmoil and crisis. In spite of the view that multilateralism should play an active role in escaping global turmoil caused by changes and developments resulting from globalization, multilateral institutions cannot fulfill their basic functions due to the policies of the countries trying to be a global power and in turn their inability to perceive the instability and global developments occurring within the global system. This necessitates that the aspects of multilateralism be reassessed within the framework of globalization with a view to escaping global turmoil. Therefore, the objective of this study is to measure the effects of institutional and socioeconomic variables on economic growth with regard to the significance of political regime types or democracy, within a government. Thus, 31 countries in two types of political regimes were included in the analysis by the period of 1984-2015. Based on this idea, the long-term institutional determinants of economic growth was analyzed with regard to political regime types in the study, and according to the results of this analysis, the socioeconomic variables in the full democracy regime group comprising of developed countries encourage economic growth. These results stem from the fact that the countries in this group have a developed social, cultural, and economic infrastructure. As a result, it has been acknowledged that multilateral institutions, which have been ineffective in producing a solution, should be reassessed within the context of recent global developments, these assessments should be performed by countries within the framework of their tendencies towards democratization and developing their sociocultural infrastructures.

Keywords: Globalization, global turmoil, multilateralism, democracy and economic growth, political regimes.

\footnotetext{
*KAPLAN, A. E. \& DAYIOĞLU ERUL, R. (2021). “ The Problem of Global Turmoil in the Dilemma of Globalization-Multilateralism: LongTerm Interactions Between Democracy and Economy within the Framework of Political Regimes", Akademi Sosyal Bilimler Dergisi, C. 8, S. 22, s. 204-224.

Makale Geliș Tarihi: 04 Ekim 2020 Kabul Tarihi: 14 Ocak 2021
} 


\section{Genişletilmiş Özet}

Son zamanlarda küresel krizden bir kaçış noktası bulunamaması, çok taraflı kurumların artık onlardan beklenen işlevleri yerine getiremediğini göstermiştir. Bu bağlamda, demokratik ülkeler tarafından benimsenecek politikaların küresel kargaşa ve krizden kurtulmada gerekli olduğu düşünülmektedir.

Küreselleşmeden kaynaklanan değişim ve gelişmelerin neden olduğu küresel kargaşadan kaçmada çok taraflılığın etkin rol oynaması gerektiği görüşüne rağmen çok taraflı kurumlar, küresel güç olmaya çalışan ülkelerin politikaları, küresel sistem içinde meydana gelen istikrarsızlık ve küresel gelişmeleri algılamadaki yetersizlikleri nedeniyle temel işlevlerini yerine getirememektedir. $\mathrm{Bu}$, küresel kargaşadan kaçmak için çok taraflılığın yönlerinin küreselleşme çerçevesinde yeniden değerlendirilmesini gerektirmektedir.

Tek küresel güç olarak değerlendirilen Amerika Birleşik Devletleri’nin benimsediği politikalar uluslararası bir etkiye sahip olsa da küresel istikrarsızlığın giderilememesinin nedeni, küresel güç olmak isteyen ulusların güçlü bir ekonomik ve politik yapıya ve bunlara ek olarak gerekli sosyal ve kültürel altyapıya sahip olamamasıdır. Bu durum da güçlü bir sosyokültürel altyapıya ve dolayısıyla güçlü bir demokrasiye sahip ülkelerin izledikleri politikaların küresel krizin ve küresel çalkantının yarattığı istikrarsızlığın giderilmesinde etkili olacağı fikrini beraberinde getirmektedir.

Bu nedenle çalışmanın amacı, bir hükümetin yönetilmesinde etkili olan siyasi rejim türlerinin veya demokrasinin önemi açısından kurumsal ve sosyoekonomik değişkenlerin ekonomik büyüme üzerindeki etkilerini ölçmektir. Bu doğrultuda 1984-2015 döneminde, Economist Intelligence Unit sınıflandırması dikkate alınarak otoriter rejim (12 ülke) ve tam demokrasi rejimi (19 ülke) olmak üzere iki tür siyasi rejimdeki 31 ülke analize dahil edilmiştir. Güvenlik, ekonomi ve demokrasi kapsamında küresel kargaşa ve çok taraflılı̆̆ yeniden değerlendirmek için toplam 31 ülke dikkate alınmış ve ekonomik büyümenin kurumsal belirleyicilerinin iki farklı rejim türü altında belirlenmesi amaçlanmıştır. Bu çerçevede; Rodrik, Subramanian ve Trebbi (2004) ve Acemoğlu, Johnson ve Robinson (2001) tarafından geliştirilen ve üretim fonksiyonundan türetilen modeller, panel veri analizi yöntemi ile tahmin edilmektedir. Çalışmada ekonomik büyüme oranı bağımlı değişken, yatırım profili, iç çatışma, dış çatışma, sosyoekonomik sınıf, yolsuzluk, hukuk ve düzen, demokratik hesap verebilirlik ve askerin siyasette etkisi indeksleri olmak üzere sekiz bağımsız değişken yer almaktadır.

Çalışmada ekonomik büyümenin uzun vadeli kurumsal belirleyicileri siyasi rejim türleri açısından incelenmiş ve analizin sonuçlarına göre gelişmiş ülkelerden oluşan tam demokrasi rejimi grubundaki sosyoekonomik değişkenlerin ekonomik büyümeyi teşvik ettiği gözlemlenmiştir. Bu sonuçlar, bu gruptaki ülkelerin gelişmiş bir sosyal, kültürel ve ekonomik altyapıya sahip olmasından ileri gelmektedir. Nitekim, gelecekte küresel sorunların çözümünde önemli rol oynayacağı düşünülen çok taraflı kurumlar ve çok taraflılık, Avrupalı kurumların bazılarını içeren bu ülkelerde, bir mesele olmaktan çok bir araya gelme çabası ve demokratikleşme ile beraber bir yaşam biçimi olarak görülmekte ve bu nedenle de yüksek düzeyde önem taşımaktadır.

Küresel kriz ve kargaşadan kaçmanın en etkili yolu, yukarıda belirtilen nedenlerle ülkelerin demokratikleşme eğilimleri çerçevesinde sosyoekonomik altyapılarını geliştirmeleri ve en demokratik rejim türlerine sahip gelişmiş Avrupa ülkelerine benzer şekilde, çok taraflı kurumların algısını daha iyi hale getirecek düzenlemeler yapılması olarak kabul edilmektedir. Nitekim, son küresel değişimler çerçevesinde ekonomik eğilimlere sosyal bir boyut getirerek günümüzün küresel sorunlarına çözüm bulamayan çok taraflı kurumların yeniden değerlendirilmesi, etik değerlendirmelerin ve dünya demokrasisinin ön plana çıkarılması, bölgesel eşitsizlikleri giderebilecek politikaların benimsenmesi, çok taraflı kurumların gelişmekte olan veya az gelişmiş ülkelerin katılımına açık toplantılar düzenlemesi gibi uygulamaların; çok taraflı kurumların eksikliklerinin giderilmesinde ve gelecekte küresel kargaşanın yaratacağı istikrarsızlığın sona ermesinde etkili olacağı tahmin edilmektedir. 


\section{Introduction}

The role of multilateral agreements and organizations in world politics has been changing and developing rapidly in the context of globalization (Hellsten, 2006:422). A surge of nationalist sentiment, uncovered in recent political processes in parts of the world, has laid bare deep cracks in the very foundations of the international systems and its two major pillars - globalization and multilateralism (ECOSOC, 2016). At the root of this destabilization of the global institutional system have been several trends ranging from economic crises to deep-rooted imbalances that require solutions at global, regional and national levels (ECOSOC, 2016:1).

New global systems resulting from national and international changes and developments brought along by globalization and policies adopted by countries to preserve their powers within the global system push the solutions that can be produced by multilateral institutions for regional and global problems of health, environment, security, economy, and culture into the background. This causes multilateral institutions to be ineffective in meeting the requirements of globalization, fail to fulfill the basic functions expected from them and have lower success levels, and thus, leads the aspects about multilateral institutions to be re-debated within the context of globalization.

In the study, after analyzing the importance of multilateral institutions and global cooperation in solving the problems caused by globalization, the role of democracy in escaping global turmoil formed within the scope of global changes will be analyzed in terms of classifications under the regime of democracy, and the role of the social and economic determinants of economic growth in policymaking within economic globalization will be put forward with regards to political orders.

\section{The Concept of Multilateralism within the Framework of Its Relations with Globalization, Its Significance and Its Functions}

\subsection{The Concept of Multilateralism and Cases Threatening Multilateralism}

While several concepts in contrast to multilateralism are debated in parallel with social, economic, and cultural national/international changes brought by globalization such as unilateralism and bilateralism, multilateralism is generally defined as an institutional form which coordinates relations among three or more states on the basis of "generalized" principles of conduct - that is, principles which specify appropriate conduct for a class of actions, without regard to the particularistic interests of the parties or the strategic exigencies that may exist in any specific occurrence (Ruggie, 1992).

The values and institutions of multilateralism are not ahistorical phenomena; as they are created and maintained in the context of specific demands and challenges, and through specific forms of leadership, norms, and international power configurations, all of these factors evolve and change and multilateralism is destined to evolve as a function of changing environmental dynamics and demands (Newman, Thakur, and Tirman, 2006:1). As a result of this, the relationship between the 
distribution of power, the nature of challenges and problems, and the international institutions that emerge to deal with collective challenges is constantly in flux (Newman, Thakur, and Tirman, 2006:1).

Even though it is regarded to be natural that the values related to multilateralism make progress parallel to the economic and social national/international order and globalization in constant flux and development, multilateralism bears a meaning beyond being an international order especially for European countries. As a matter of fact, multilateralism is seen as a way of life rather than as a question of power, international order or structural change because it is the means by which Europeans have tried, with a considerable degree of success, to reconcile togetherness and diversity (Groom, 2006:460).

Several factors affect the efficiency of and expectations from the contemporary forms of multilateralism (Newman, Thakur and Tirman, 2006:2-4):

- The relationship between the distribution of power at the international level -in all its dimensions, hard and soft- and the nature of multilateralism is fundamental.

- Many of the challenges confronting multilateral institutions have been associated with US military and economic preeminence in a unipolar world, and an attendant pattern of US unilateralism. Multilateral institutions are inherently vulnerable to hegemonic/unilateralist power, demonstrated vividly during the UN Security Council's failure to constrain the US misadventure in Iraq.

- In some other cases, factors confronting multilateralism stem from not the distribution of power within inter-state relations or policies adopted by a country/countries, but challenges caused by structural and normative changes since the forming of multilateral institutions following the Second World War (to illustrate, security problems having increasingly become a non-state issue).

- Although international organizations emerged from the need to regulate and give predictability to a narrow range of inter-state relations, in their decision-making procedures and their representation, many international organizations do not meet contemporary standards and expectations of legitimacy based upon accountability and democracy.

- Existing multilateral arrangements are unable to guide states to a workable framework of how to deal with egregious and widespread abuses of human rights and civil war.

- The state-centric nature of multilateralism and states' ways of making and adopting decisions are inefficient in addressing many of these challenges.

- There are policy (and knowledge) failures, such as the World Bank's imposition of structural adjustment policies which have been associated with negative social consequences. 


\subsection{Multilateralism and Globalization}

Changes and developments having come to life within the scope of globalization in the development process of multilateralism shook the belief for multilateralism especially during the early 21 st century, which continues to dwindle to this day due to the current global turmoil. Therefore, this inter-state structure which defines multilateralism fails to solve today's problems.

While globalization is regarded to be a threat for the future of multilateralism, it should not be ignored that multilateral institutions can play a vital role in producing solutions to the global problems brought about by global developments such as migration, drought, terrorism incidents, epidemics, and poverty. Accordingly, multilateral organizations are the best tool we have to transform globalization into prosperity (The Wilson Center, 2007).

The importance of multilateralism and multilateral organizations in solving the problems caused by globalization is seen in Figure 1. In the figure, the functionality of organizations with regard to qualities such as efficiency, transparency, and encouragement are presented in terms of USA global fund, average bilateral, average multilateral, and average overall. It can be clearly seen here that the multilateral organizations have significantly higher performance levels on average especially compared to bilateral organizations and, in terms of almost every criterion, all the organizations found in the figure.

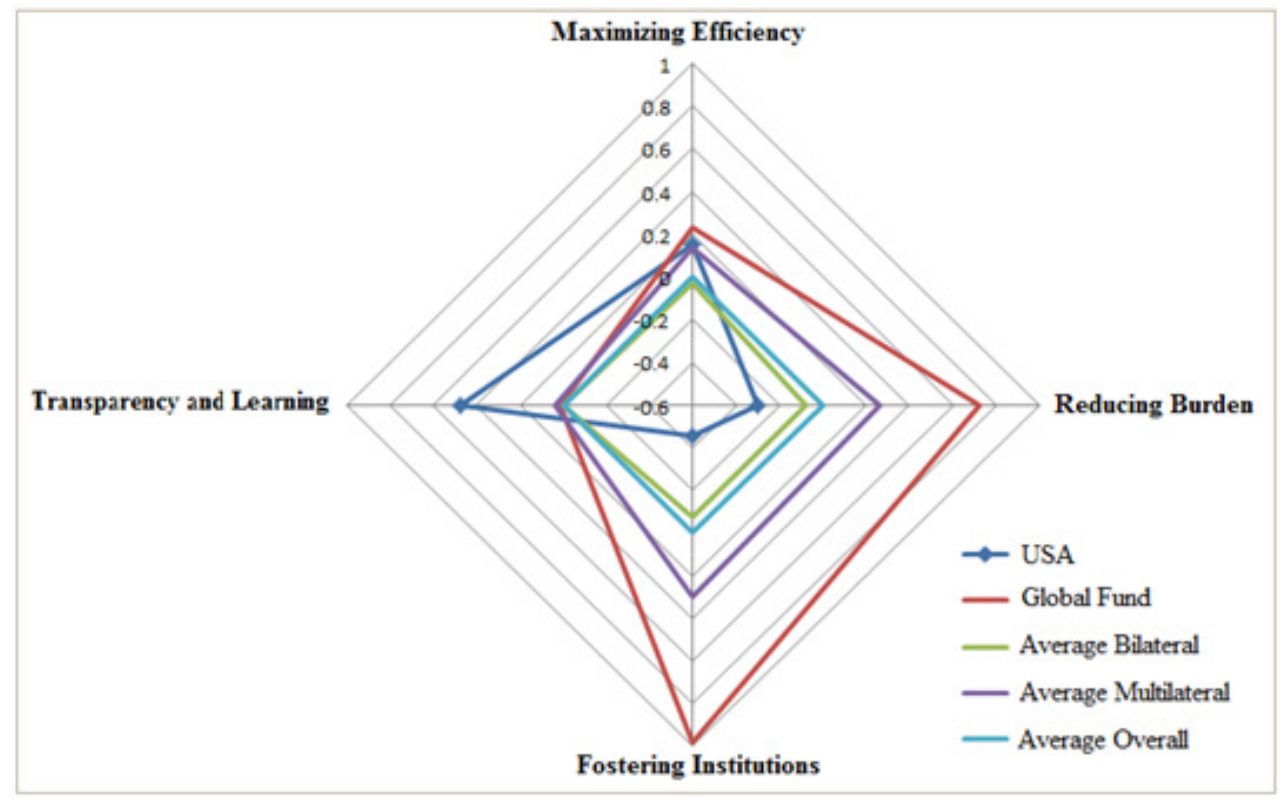

Figure 1. The Importance of Multilateral Institutions

Source: A. Glassman, 2012. 'GHI 2013 and the Rise of Multilateralism'. Retrieved 05.12.2018, https://www.cgdev. org/blog/ghi-2013-and-rise-multilateralism.

Although multilateral organizations have recently focused themselves on finding solutions especially for global health problems, there are a number of multilateral organizations that function in terms of various other issues. The most commonly known among these are institutions like 
the European Union, the OECD, the World Bank and the UNESCO, while there are also several multilateral organizations found within the global organizations, Americas, Asia, and Middle East/Africa categorizations. Although the number of such organizations is extremely high in our day, how much they succeed in fulfilling their purposes is debatable.

On the grounds that the inability of multilateralism to function as desired causes global turmoil to gradually increase, multilateralism should be readdressed in terms of its different aspects for such functions to be fulfilled. In order for multilateralism to have a future and to be a useful force in guiding the world economy towards social justice, there is a need to take account of our global rights and responsibilities seriously and equally (Hellsten, 2006:438). States need to take control over the various trends of globalization by adding a social dimension to economic trends and this entails that regionalism is used for balancing the interests of different regions and bringing in the different concerns on the international negotiating table (Hellsten, 2006:438). If we can bring ethical debate on values back on the agenda of international politics, multilateral arrangements can play an important role in controlling the negative effects of globalization and also to take into account the social dimensions of globalization (Hellsten, 2006:438). In addition to these, the process of innovative multilateralism cannot succeed without addressing the issues of security both at the regional and global level (Telò, 2013:7).

On the other hand, as in the areas of social and economic welfare and humanitarianism, non-state actors are an essential component of multilateralism which must be embraced fully, multilateral institutions must recognize and involve non-state actors on the basis of criteria which ensure their legitimacy and effectiveness (Newman and Thakur, 2006:539). In this sense, the multilateralism of the twenty-first century must not be confined to relationship amongst states; it must reflect the plurality of international relations and the key role of non-state actors (Newman and Thakur, 2006:539).

\section{The Importance of Economy and Democracy in the Cycle of Globalization and Global Turmoil}

\subsection{The Link between Globalization and Global Turmoil}

Interactions between the momentum of historical events, the limit of the capabilities we use to shape the world, the ever-increasing financial needs, and moral ambiguities produce new developments that we cannot control, and are the momentum of the changes that shape the future and gradually increase on the basis of societies' needs and in addition to this, since the humankind wants to organize itself as a global society, the world politics go out of control, and mass political confusions and philosophical complexities appear on the basis of both international relations and national social needs as a result of these tendencies (Brzezinksi, 1995:xiii-xiv).

Countries heavily dependent on the global economy are likely to experience higher economic growth, greater affluence, more democracy and increasingly peaceful conditions at home and abroad 
(Gissinger and Gleditsch, 1999) but globalization may sometimes be a threat, not an opportunity. Thusly, the most distinct characteristic of contemporary history has been its instability due to the changes caused by globalization (Brzezinksi, 1995:x). One of the most basic indicators supporting this is that the United States of America appears to be the single global power but does not have the infrastructure to maintain this. However, in spite of the globalization upheaval, a key independent variable of international relations remains constant - power and this case demonstrates that power remains the key independent variable shaping modern international relations (Kay, 2004).

In this atmosphere in which the USA has the power, traditional politics turn into international politics and the differences between national and international politics disappear as a result of modern communication and mutual economic dependencies; however, the inability of the USA to provide an efficient global authority within these politics due to its shortcomings caused by global factors, in spite of its economic power and managing a global process of political procedures, can lead to intensified instability in global terms (Brzezinksi, 1995:xiii).

Within the framework of the developments caused by the aforementioned reasons, trying to dominate the world and be the leader in policy determination on the part of the USA, changes occurring throughout the world following the September 11 attacks, the relationships of countries with the USA in parallel with their domestic politics and dynamics, wars of power waged among nations and their all kinds of efforts to have a part in the world economy in order to obtain resources with the aim of enriching their economies all leave traces of differentiation observed in the balances of power with each passing day and thus, leads to global turmoil.

On the other hand, expectations and desires of today's societies and people also strengthen the atmosphere of global turmoil. Since the main purpose of people of our day, apart from the wealthy western countries, is not significant consumption but survival, these unusual tendencies hinder a global reconciliation and enhance the dangers of global segregation (Brzezinksi, 1995:xii).

Social and individual demands, including multilateralism, should be reassessed on a conceptual basis due to several factors caused by global turmoil. Firstly, there is a need for a new definition of political existence that is more extensive and globally relatable, which is actually mutual solidarity among people, for which it is necessary to create a constant balance between social needs and individual satisfaction, global poverty and national wealth, natural heritages that have to be preserved by humans, and creating a safe environment for people (Brzezinksi, 1995:xiv). At this very juncture, the importance of reassessing multilateralism within the framework of new impressions and demands resulting from these factors and global turmoil becomes clear.

Unlike previous eras, the contemporary international system contains no major contests of territory or ideology among the major powers; but at the same time, new threats such as terrorism, disease, climate change and the spread of weapons of mass destruction gives all the major powers a stake in maintaining stability and spreading peace and security (Lennon and Kozlowski, 2008:vii). This 
both causes the countries that have a say or want to have a say in the world economy and politics to adopt policies accordingly and reveals the importance of international institutions and organizations in policymaking. Global cooperation under these conditions is both a unique opportunity and an imperative (Lennon and Kozlowski, 2008:vii).

\subsection{The Effects of Economy and Democracy on Global Turmoil}

The shortcomings of international organizations in terms of governance and accountability, the speed of economic globalization surpassing the developmental speed of political institutions needed to manage the process properly, political responses needing to be produced on a global scale but instead given on a national scale, and the inefficiency of the current international organizations and institutional regulations in taking precautions to prevent global crisis provide a unique opportunity to make a reform in the field of global economy management with a view to revealing the inefficiencies of current regulations in financial and economic crisis and proving the need for cooperation and coordination to fight the crisis (Stiglitz, 2010:121-122-194-196).

Since the problems related to issues such as health, terror, environment, natural resources etc. created by globalization cause global turmoil in humane and geopolitical terms, the solutions for these problems should be global. In this regard, powerful joint movements and cooperation should be performed on a global scale to fulfill mutual purposes, determine the conditions of use of especially regional and global public goods properly, and attain the great goals agreed in the United Nations summits and conferences in the last twenty years (Stiglitz, 2010:122-123).

In parallel with this view, Brzezinski sees the way out of the global turmoil and crisis in providing global cooperation among countries in an intercontinental system. However, what kind of criteria should be held in forming such an intercontinental system is ambiguous; this actually goes to show that powerful countries want to form all the systems planned in our day to seek after methods that can provide their own strategic interests, gives the impression that these countries do not have a model regarding a just solution for regional disputes (Newtimes.az, 2013) .

Since people live in a highly globalized world economy in our day, there is a mainstream thought that a greater international economy and financial connections can improve democracy (Acemoglu and Robinson, 2006:358). Indeed, in spite of the thought that the current democracy regimes have been unable to solve the problems created by globalization, the inverse idea that globalization can help consolidate democracy supports this assessment (Acemoglu and Robinson, 2006:334). This idea stems from the thought that the international trade increasing due to globalism will decrease balance taxes, the decreased taxes will make it more possible for democracy to be adopted, and class conflicts between elites and citizens will be less intense in more globalized countries (Acemoglu and Robinson, 2006:334).

The concept of globalization is a dialectical one by its very nature, politico-economic and sociocultural counter-tendencies (Gill, 1997:5). There are views that democracy increases GDP 
by encouraging investment, increasing schooling, inducing economic reforms, improving the provision of public goods, and reducing social unrest (Acemoglu, Naidu, Restrepo and Robinson, 2019). Indeed, wealthy nations tend to be more democratic (Acemoglu and Robinson, 2006:334).

Based on these views and assessments, the objective of the study has been determined as investigating what kind of effects democracy has on long-term economic growth within the context of social and economic factors affecting GDP. At this juncture, the study will be performed by classifying countries according to their democracy status (political regimes), and a course will be set regarding democracy-economic growth- socioeconomic variables-globalization with regard to these country groups.

\subsection{Literature Review on the Relation between Democracy/Political Regimes and Economic Growth}

Numerous studies have up to now tried to put forward the effects of democracy on economic growth with regard to political regimes. The literature on the regime type and economic performance is presented in Table 1 in terms of samples, time periods and results.

Table 1. Literature on Political Regimes and Economic Growth

\begin{tabular}{|c|c|c|c|}
\hline Author & Sample & Time Frame & Finding \\
\hline Przeworski (1966) & 57 Countries & $1949-1963$ & Dictatorship at medium development level grew fastest \\
\hline Dick (1974) & $\begin{array}{l}59 \text { Underdeveloped } \\
\text { Countries }\end{array}$ & $1959-1968$ & Democracies develop slightly faster \\
\hline $\begin{array}{l}\text { Huntington and } \\
\text { Dominguez (1975) }\end{array}$ & $\begin{array}{l}35 \text { Underdeveloped } \\
\text { Countries }\end{array}$ & the $1950 \mathrm{~s}$ & Authoritarian grew faster \\
\hline $\begin{array}{l}\text { Berg-Schlosser } \\
\quad(1984)\end{array}$ & 36 African Countries & $1960-1975$ & $\begin{array}{c}\text { There are real differences among regime types, the } \\
\text { pattern of these differences depends on the particular } \\
\text { measure of economic progress examined }\end{array}$ \\
\hline Landau (1986) & 65 Countries & $1960-1980$ & Authoritarian grew faster \\
\hline $\begin{array}{c}\text { Sloan and } \\
\text { Tedin (1987) }\end{array}$ & $\begin{array}{l}20 \text { Latin American } \\
\text { Countries }\end{array}$ & 1960-1979 & $\begin{array}{l}\text { Bureaucratic-authoritarian regimes do better than } \\
\text { democracy; traditional dictatorships do worse }\end{array}$ \\
\hline Barro (1989) & 72 Countries & $1960-1985$ & Democracies grew faster \\
\hline $\begin{array}{l}\text { Grier and Tullock } \\
\text { (1989) }\end{array}$ & 59 Countries & $1961-1980$ & $\begin{array}{c}\text { Democracy in Africa and Latin America better, no regime } \\
\text { difference in Asia country }\end{array}$ \\
\hline Remmer (1990) & $\begin{array}{l}11 \text { Latin American } \\
\text { Countries }\end{array}$ & $1982-1988$ & Democracies grew faster \\
\hline Helliwell (1992) & 125 Countries & $1960-1985$ & The effects of democracy on growth are found positive \\
\hline $\begin{array}{l}\text { Mulligan, Gil and } \\
\text { Sala-I-Martin (2004) }\end{array}$ & 102 Countries & $1960-1990$ & $\begin{array}{l}\text { A number of policies and redistribution policies, such as } \\
\text { state social security expenditures, do not differ between } \\
\text { democracies and dictatorship. }\end{array}$ \\
\hline $\begin{array}{c}\text { Persson and } \\
\text { Tabellini (2007) }\end{array}$ & $\begin{array}{l}123 \text { Democratic Countries } \\
70 \text { Autocratic Countries }\end{array}$ & $1960-2000$ & $\begin{array}{c}\text { The positive effect of transitions to democracy appears } \\
\text { larger in absolute value (and in one case statistically } \\
\text { significant) than the negative effect of transitions to } \\
\text { autocracy. }\end{array}$ \\
\hline Jamali et al. (2007) & 92 and 58 countries & 1990-1999 & $\begin{array}{c}\text { Democracies and bureaucracies significantly outperform } \\
\text { autocracies. }\end{array}$ \\
\hline
\end{tabular}




\section{Estimation Methods}

\subsection{Cross Section Dependency Tests}

The methods used to test cross-section dependency on panel data sets are the Breusch-Pagan (1980) CDLM1 test, the Pesaran (2004) CDLM2 test, and the Pesaran et al. (2008) Bias Adjusted CD test.

H0: No cross section dependency

H1: Cross section dependency

When the probability values are lower than 0.05 in the results to be obtained from the BreuschPagan (1980) CDLM1 test, the Pesaran (2004) CDLM2 test, and the Pesaran et al. (2008) Bias Adjusted CD test, $\mathrm{H} 0$ is rejected with a 5\% significance level, and cross-section dependency is determined to exist among the units constituting the panel.

$$
\begin{aligned}
& C D_{L M 1}=T \sum_{i=1}^{N-1} \sum_{j=i+1}^{N} \hat{\rho}_{i j}^{2} \\
& C D_{L M 2}=\left(\frac{1}{N(N-1)}\right)^{1 / 2} \sum_{i=1}^{N-1} \sum_{j=i+1}^{N}\left(T \hat{\rho}_{i j}^{2}-1\right) \\
& C D_{\text {Bias Adjusted }}=\left(\frac{2}{N(N-1)}\right)^{1 / 2} \sum_{i=1}^{N-1} \sum_{j=i+1}^{N} \hat{\rho}_{i j}^{2} \frac{(T-K-1) \hat{\rho}_{i j}-\widehat{\mu}_{T i j}}{v_{T i j}} \sim N(0,1)
\end{aligned}
$$

$\hat{\rho}_{i j}, \hat{\mu}_{T i j}$, and $v_{T i j}$ represent the estimates of cross section dependencies among the residuals, the mean, and the variance respectively. The $C D_{L M 1}$ and $C D_{L M 2}$ tests are used when $\mathrm{T}>\mathrm{N}$, and the $C D_{\text {Bias Adjusted }}$ test is used when $\mathrm{N}>\mathrm{T}$.

\subsection{Testing the Homogeneity of Cointegration Coefficients}

In this test;

$$
Y_{i t}=\alpha+\beta_{i} X_{i t}+\varepsilon_{i t}
$$

Whether the $\beta_{i}$ slope coefficients are different among the cross sections in a general cointegration equation as shown in $\mathrm{D} 4$ is tested. The hypotheses of the test are:

$\mathrm{H}_{0}: \beta_{i}=\beta$ slope coefficients are homogeneous.

$\mathrm{H}_{1}: \beta_{i} \neq \beta$ slope coefficients are not homogeneous.

Pesaran and Yamagata (2008) developed two different test statistics to test the hypotheses.

For large samples: $\widehat{\Delta}=\sqrt{N} \frac{N^{-1} \tilde{S}-k}{\sqrt{2 k}}$

For small samples: $\widehat{\Delta}_{a d j}=\sqrt{N} \frac{N^{-1} \tilde{S}-k}{\sqrt{\operatorname{Var}(t, k)}}$

Here, N, S, k, and $\operatorname{Var}(\mathrm{t}, \mathrm{k})$ represent the cross section number, Swamy test statistics, the explanatory variable number, and standard error respectively. The $\mathrm{H}_{0}$ hypothesis is rejected on a related significance level when the probability value is lower than 0.05 , and the $\mathrm{H}_{1}$ hypothesis is accepted. Thus, the cointegration coefficients are acknowledged to be non-homogeneous. 


\subsection{Hadri-Kruzomi Unit Root Test}

The Hadri-Kruzomi (2012) test is the result of adapting the KPSS test in a time series as a second generation panel unit root test regarding cross-section dependency. Firstly, the following model is estimated:

$Y_{i t}=z_{t}^{\prime} \delta_{i}+f_{t} \gamma_{i}+\varepsilon_{i t}, \quad \varepsilon_{i t}=\emptyset_{i 1} \varepsilon_{i t-1}+\cdots+\emptyset_{i t} \varepsilon_{i t-p}+v_{i t}$

Based on these equations, the Hadri-Kruzomi test statistics are calculated as follows;

$Z_{A}^{S P C}=\frac{1}{\widehat{\sigma}_{i S P C}^{2} T^{2}} \sum_{t=1}^{T}\left(S_{i t}^{W}\right)^{2}$

$Z_{A}^{L A}=\frac{1}{\hat{\sigma}_{i L A}^{2} T^{2}} \sum_{t=1}^{T}\left(S_{i t}^{W}\right)^{2}$

The null and alternative hypotheses of the Hadri-Kruzomi test are as follows;

$H_{0}: \emptyset_{i} \neq 0$; the series are non-stationary

$H_{0}: \emptyset_{i}=0$; the series are stationary

\subsection{Durbin-Hausman Panel Cointegration Test}

The cointegration relationship between the series in this study was analyzed with the DurbinHausman panel cointegration test developed by Westerlund (2008). The Durbin-Hausman panel cointegration test provides an opportunity to perform a cointegration analysis when the independent variables are $\mathrm{I}(1)$ or $\mathrm{I}(0)$ and the dependent variables are $\mathrm{I}(1)$ and takes into account mutual factors. In the Durbin-Hausman method, Westerlund (2008) examined the existence of the cointegration relationship with two different tests, the first of which is the Durbin-Hausman panel test and the second of which is the Durbin-Hausman group test. Westerlund (2008) enables the autoregressive parameters to differentiate among the sections in the Durbin-Hausman group test. The hypotheses of this test are as follows; $\mathrm{H}_{0}$ : No cointegration; $\mathrm{H}_{1}$ : Cointegration relationship among at least a few sections. In the Westerlund (2008) Durbin-Hausman panel test, autoregressive parameters are acknowledged to be the same for all the sections. The hypotheses are H0: No cointegration, H1: Cointegration relationship throughout the whole panel. The Durbin-Hausman test statistics are calculated with;

$$
\begin{aligned}
& D H_{g}=\sum_{i=1}^{N} \hat{S}_{i}\left(\widetilde{\emptyset}_{i}-\widehat{\emptyset}_{i}\right)^{2} \sum_{t=2}^{T} e_{i t-1}^{2} ; \\
& D H_{p}=\hat{S}_{n}\left(\widetilde{\emptyset}_{i}-\widehat{\emptyset}_{i}\right)^{2} \sum_{i=1}^{n} \sum_{t=2}^{T} e_{i t-1}^{2} ;
\end{aligned}
$$

\subsection{Panel Autoregressive Distributed Lag (ARDL) Model}

For the estimations of short and long-term coefficients following the cointegration relationship, Pesaran, Shin and Smith (1999) developed the panel autoregressive distributed lag (ARDL) model, i.e., two different estimators, namely the Mean Group Estimator (MGE) and the Pooled Mean Group Estimator (PMGE). The mean group estimator (MGE) does not limit the parameters of the ARDL specification in any way and obtains long-term parameters from the mean of long-term 
parameters calculated from individual ARDL estimations. The main shortcoming of this estimator is that it allows specific parameters to be the same among the units constituting the panel. This shortcoming observed in MGE is compensated for in the pooled mean group estimator (PMGE). PMGE limits the long-term parameters to be the same among the countries constituting the panel but allows the constant, the error variance, and the short-term parameters to vary depending on the country. Therefore, PMGE allows the variables to be heterogeneous in short-term in relation to allowing them to be homogeneous in long-term. Pesaran, Shin and Smith (1999) stated that whether the long-term parameters are homogeneous could be determined by performing the Hausman test (1978), and accordingly recommended the test. In the Hausman test, while the null hypothesis is that "the parameters are homogeneous in long-term", while in the alternative hypothesis, the proposition that "the parameters are heterogeneous in long-term" is tested. At this juncture, PMGE is preferred if the null hypothesis is accepted, and MGE is preferred if the null hypothesis is rejected. In terms of the long-term homogeneity assumption, MGE is a consistent estimator, while PMGE is both consistent and effective.

\section{The Dataset and Models}

\subsection{The Dataset}

Within the framework of the Economist Intelligence Unit's Democracy Index, two regime types were taken into consideration, namely authoritarian regime and full democracy. 31 countries in total were included in the analysis, 12 for authoritarian regime and 19 for full democracy, while time dimension spans the 32-year period between the years 1984 and 2015.

The characteristics of two country groups formed according to the democracy index are as follows (Economist Intelligence Unit, 2018:64):

- Authoritarian regimes: In these states, state political pluralism is absent or heavily circumscribed. Many countries in this category are outright dictatorships. Elections, if they do occur, are not free and fair. There is disregard for abuses and infringements of civil liberties. Media are typically state-owned or controlled by groups connected to the ruling regime. There is repression of criticism of the government and pervasive censorship. There is no independent judiciary.

- Full democracies: Countries in which not only basic political freedoms and civil liberties are respected, but which also tend to be underpinned by a political culture conducive to the flourishing of democracy. The functioning of government is satisfactory. Media and the judiciary are independent. There are only limited problems in the functioning of democracies.

Since the variable of gross domestic product per capita growth rate is the most significant indicator of economic performance, it was regarded as a dependent variable. The gross domestic product per capita growth rate data (\%), abbreviated as PDGP, was obtained from the World Bank for 
the time period of 1984-2015. The investment profile (IP) index represents the factors affecting the investment risk; the internal conflict index (IC) represents the political violence occuring within the country and the effects it has on the government; the index of external conflict (EC) represents the status of being exposed to interventions from foreign countries and the varying degrees of non-violent external pressures (canceling diplomatic aid, trade limitations, regional disputes, legal sanctions etc.); the index of socioeconomic class (SC) represents the evaluation of socioeconomic pressures observed in the society resulting from limitations or dissatisfaction caused by governmental operations and the components of unemployment, consumer trust, and welfare; the index of corruption (CO) represents the level of corruption within the political structure; the index of law and order (LO) represents the objectivity and power of the legal system while its sub-components of regulations represent the effects of the legal system on the society; the index of democratic accountability (DA) represents a measurement of the government's level of sensitivity for its people; lastly, the index of military impact on politics (MIP) represents is measurement of the intervention levels of military power having come to power by assignment on political will. Data related to these variables were obtained from the consulting firm Political Risk Services-International Country Risk Guide (PRS-ICRG, 2014).

\subsection{The Models}

In order to reassess global turmoil and multilateralism within the scope of security, economy, and democracy, 31 countries in total were taken into account and the institutional determinants of economic growth were intended to be determined under two different regime types. Within this framework, two models, developed by Rodrik, Subramanian and Trebbi (2004) and Acemoglu, Johnson and Robinson (2001) and derived from production function, are estimated. The matches are as follows:

a) The first model for authoritarian regimes;

(Model 1)

$P G D P_{i t}=\alpha_{0}+\alpha_{1} I P_{i t}+\alpha_{2} I C_{i t}+\alpha_{3} E C_{i t}+\alpha_{4} S C_{i t}+\alpha_{5} C O_{i t}+\alpha_{6} L O_{i t}+\alpha_{7} D A_{i t}+\alpha_{8} M I P_{i t}+\varepsilon_{i t}$

b) The second model for full democracies;

(Model 2)

$P G D P_{i t}=\eta_{0}+\eta_{1} I P_{i t}+\eta_{2} I C_{i t}+\eta_{3} E C_{i t}+\eta_{4} S C_{i t}+\eta_{5} C O_{i t}+\eta_{6} L O_{i t}+\eta_{7} D A_{i t}+\eta_{8} M I P_{i t}+\varepsilon_{i t}$

Here; PDGP, IP, IC, EC, SC, CO, LO, DA, MIP, $\mathrm{i}=1,2,3, \ldots, \mathrm{N}$, and $\mathrm{t}=1984,1985,1986, \ldots, 2015$ represent gross domestic product per capita growth rate, the index of investment profile, the index of internal conflict, the index of external conflict, the index of socioeconomic class, the index of corruption, the index of law and order, the index of democratic accountability, the index of military impact on politics, the dimensions of cross section i.e. countries, and time dimension respectively. 


\subsection{Empirical Findings}

Descriptive statistics regarding the variables on two models constituted to determine the long-term institutional determinants of economic performance in terms of regime type are given in Table 2.

Table 2. Descriptive Statistics

\begin{tabular}{|c|c|c|c|c|c|c|c|c|c|}
\hline \multicolumn{10}{|c|}{ Authoritarian Regime Descriptive Statistics } \\
\hline & PGDP & IP & IC & EC & $\mathrm{SC}$ & $\mathrm{CO}$ & LO & DA & MIP \\
\hline Mean & 1.37 & 6.80 & 8.51 & 9.08 & 5.49 & 2.47 & 3.65 & 2.57 & 2.93 \\
\hline Median & 1.74 & 6.92 & 8.75 & 9.92 & 5.50 & 2.48 & 3.95 & 2.93 & 3.00 \\
\hline Maximum & 22.72 & 11.50 & 12.00 & 12.00 & 11.00 & 4.00 & 6.00 & 5.00 & 5.00 \\
\hline Minimum & -14.57 & 1.00 & 0.25 & 0.00 & 2.00 & 1.00 & 0.00 & 0.00 & 0.00 \\
\hline Std. Dev. & 4.94 & 2.06 & 2.24 & 2.26 & 1.85 & 0.70 & 1.09 & 1.06 & 1.63 \\
\hline Jarque-Bera & 50.73 & 0.00 & 70.77 & 231.54 & 5.79 & 16.67 & 18.87 & 14.76 & 24.54 \\
\hline Probability & 0.00 & 1.00 & 0.00 & 0.00 & 0.06 & 0.00 & 0.00 & 0.00 & 0.00 \\
\hline Observations & 384 & 384 & 384 & 384 & 384 & 384 & 384 & 384 & 384 \\
\hline \multicolumn{10}{|c|}{ Full Democracy Regime Descriptive Statistics } \\
\hline Mean & 1.99 & 9.25 & 11.03 & 11.24 & 8.18 & 4.93 & 5.52 & 5.74 & 5.79 \\
\hline Median & 2.08 & 9.50 & 11.50 & 11.50 & 8.17 & 5.00 & 6.00 & 6.00 & 6.00 \\
\hline Maximum & 25.64 & 12.00 & 12.00 & 12.00 & 11.00 & 6.00 & 6.00 & 6.00 & 6.00 \\
\hline Minimum & -11.40 & 4.00 & 6.00 & 6.50 & 4.00 & 2.00 & 2.00 & 3.08 & 2.08 \\
\hline Std. Dev. & 2.83 & 2.12 & 1.26 & 0.96 & 1.52 & 1.00 & 0.89 & 0.51 & 0.60 \\
\hline Jarque-Bera & 2187.74 & 33.13 & 539.40 & 572.67 & 14.58 & 60.89 & 1006.37 & 987.34 & 4464.29 \\
\hline Probability & 0.00 & 0.00 & 0.00 & 0.00 & 0.00 & 0.00 & 0.00 & 0.00 & 0.00 \\
\hline Observations & 608 & 608 & 608 & 608 & 608 & 608 & 608 & 608 & 608 \\
\hline
\end{tabular}

According to the cross-section dependency test results, all the variables in two models through which we tried to determine the long-term institutional determinants of economic performance in terms of two regime types are dependent on each other in cross-sectional terms, i.e. there is a crosssection dependency. The optimal methods taking this into account will be utilized in the other parts of the analysis.

Whether the long-term parameters were homogeneous was analyzed through the Delta Test developed by Pesaran and Yamagata (2008), the results of which are given in Table 3. In the results obtained regarding two models in terms of two different regime types, the null hypothesis was rejected while the alternative hypothesis was accepted. Thus, it was concluded that the slope coefficients were heterogeneous. 


\begin{tabular}{|l|c|c|c|c|}
\hline \multicolumn{4}{|c|}{ Table 3. Delta Test Statistics } \\
\hline & \multicolumn{2}{|c|}{$\begin{array}{c}\text { Authoritarian } \\
\text { Regime }\end{array}$} & \multicolumn{2}{c|}{$\begin{array}{c}\text { Full Democracy } \\
\text { Regime }\end{array}$} \\
\hline & First Model & \multicolumn{2}{c|}{ Second Model } \\
\hline & Stat. & prob. & Stat. & prob. \\
\hline $\begin{array}{l}\text { Delta_tilde: } \\
\text { Delta_tilde_adj: }\end{array}$ & $2.01^{* *}$ & 0.02 & $1.54^{*}$ & 0.06 \\
\cline { 2 - 3 } & $2.41^{* * *}$ & 0.01 & $1.86^{* *}$ & 0.03 \\
\hline \multicolumn{3}{|c|}{ N=12 } & N=19 \\
\hline${ }^{* * *},{ }^{* *}$ and ${ }^{*}$ are statistically significant at 1\%, 5\% and 10\%, \\
\multicolumn{4}{|c|}{ respectively. } \\
\hline
\end{tabular}

According to The Hadri-Kruzomi unit root test results, the GDP variable which is a dependent variable of all two models includes unit root.

Table 4. Durbin-Haussman Test Statistics

\begin{tabular}{|l|c|c|c|c|}
\hline & \multicolumn{2}{|c|}{$\begin{array}{c}\text { Authoritarian } \\
\text { Regime }\end{array}$} & \multicolumn{2}{c|}{$\begin{array}{c}\text { Full Democracy } \\
\text { Regime }\end{array}$} \\
\hline & \multicolumn{2}{|c|}{ First Model } & \multicolumn{2}{c|}{ Second Model } \\
\hline & Stat. & prob. & Stat. & prob. \\
\hline $\mathrm{dh} \_\mathrm{g}$ & $5.38^{* * *}$ & 0.00 & $66.37^{* * *}$ & 0.00 \\
\hline $\mathrm{dh} \_\mathrm{p}$ & $5.61^{* * *}$ & 0.00 & $60.39^{* * *}$ & 0.00 \\
\hline
\end{tabular}

The Durbin-Hausman cointegration test results are given in Table 4. According to dh_g and dh $\_p$ statistical results for all two models to determine the long-term institutional determinants of economic performance in terms of two regime types, the null hypothesis was rejected and the alternative hypothesis was accepted. Accordingly, the existence of a relationship between GDP per capita growth rate and the variables of investment profile, internal conflict, external conflict, socioeconomic class, corruption, law and order, democratic accountability, and military impact on politics was tested. The results indicate a long-term relationship between the addressed variables. 


\subsubsection{Authoritarian Regime Results}

Table 5. Authoritarian Regime Results

\begin{tabular}{|c|c|c|c|c|c|c|c|c|}
\hline & \multicolumn{3}{|c|}{ Pooled MGE Estimates } & \multicolumn{3}{|c|}{ MGE Estimates } & \multirow[b]{2}{*}{ h-test } & \multirow[b]{2}{*}{ p-val } \\
\hline & Coef. & St. Er. & t-ratio & Coef. & St. Er. & t-ratio & & \\
\hline \multicolumn{9}{|c|}{ Long-Run Coefficients } \\
\hline ip & $-0.46^{* * *}$ & 0.09 & -5.32 & 0.11 & 1.99 & 0.05 & 0.08 & 0.77 \\
\hline ic & $1.10^{* * *}$ & 0.13 & 8.33 & -0.23 & 1.53 & -0.15 & 0.76 & 0.38 \\
\hline ec & 0.09 & 0.11 & 0.83 & -0.25 & 1.00 & -0.25 & 0.11 & 0.73 \\
\hline sc & $-1.24^{* * *}$ & 0.17 & -7.38 & -2.90 & 1.84 & -1.57 & 0.82 & 0.37 \\
\hline co & $0.67^{* * *}$ & 0.11 & 6.27 & -2.07 & 3.61 & -0.57 & 0.58 & 0.45 \\
\hline lo & $0.55^{* * *}$ & 0.10 & 5.45 & -1.28 & 2.50 & -0.51 & 0.54 & 0.46 \\
\hline da & -0.13 & 0.09 & -1.39 & 0.98 & 0.94 & 1.04 & 1.39 & 0.24 \\
\hline \multirow[t]{2}{*}{ mip } & $0.33^{* *}$ & 0.14 & 2.36 & -2.84 & 1.65 & -1.72 & 3.71 & 0.05 \\
\hline & & & & & \multicolumn{2}{|c|}{ Joint Hausman test: } & 10.60 & 0.23 \\
\hline \multicolumn{7}{|c|}{ Error Correction Coefficients } & & \\
\hline Phi & -0 . & \begin{tabular}{|l|l}
$* * * *$ & 0.1 \\
\end{tabular} & -3.27 & -0.85 & 0.25 & -3.43 & & \\
\hline
\end{tabular}

As a result of the Hausman test performed to test whether the variables were homogeneous in long term, long-term homogeneity was concluded to exist, and the effective and consistent Pooled Mean Group Estimator (PMG) was determined to be the optimal estimator in our first model under the null hypothesis. The negative coefficient of statistically significant error correction (phi) demonstrates that there is a long-term relationship between economic growth and the institutional variables and that the balance is re-converged even when it is deviated from.

The pooled mean group estimator results regarding the group of countries governed by an authoritarian regime are shown in Table 5. According to the related results, the variables except for investment profile, socioeconomic class, and democratic accountability are observed to have a long-term effect on economic growth. The variables that have the greatest effect in order are internal conflict, corruption, law and order, military impact on politics, and external conflict (statistically insignificant). Especially the fact that the increase in the variable of law and order brings along an increase in economic growth is an expected result for this country group under which the underdeveloped or developing countries fall. However, the effects of corruption and internal conflict on economic growth is thought to result from the impact of factors like political violence on the government and its policies regarding the governance of the country and consequently the increase in economic activities through illegal methods such as corruption and usury due to degradation of the economic and financial environment.

Among the variables affecting economic growth negatively in long term, the effects of the socioeconomic class variable are observed to be extremely higher than those of the other variables. This goes to show that even the improvements to occur within the socioeconomic structure of countries cannot increase economic growth, and it is thought to be caused by the inability of such improvements to provide economic growth due to structural characteristics such as unimproved 
and disarrayed employment opportunities and limitations resulting from government policies.

\subsubsection{Full Democracy Regime Results}

Table 6. Full Democracy Regime Results

\begin{tabular}{|c|c|c|c|c|c|c|c|c|}
\hline & \multicolumn{3}{|c|}{ Pooled MGE Estimates } & \multicolumn{3}{|c|}{ MGE Estimates } & \multirow[b]{2}{*}{ h-test } & \multirow[b]{2}{*}{ p-val } \\
\hline & Coef. & St. Er. & t-ratio & Coef. & St. Er. & t-ratio & & \\
\hline \multicolumn{9}{|c|}{ Long-Run Coefficients } \\
\hline ip & $0.24^{* * *}$ & 0.06 & 3.79 & -2.19 & 1.04 & -2.11 & 5.48 & 0.02 \\
\hline ic & $0.20^{* *}$ & 0.08 & 2.38 & -0.50 & 2.14 & -0.24 & 0.11 & 0.74 \\
\hline ec & $0.55^{\text {***}}$ & 0.07 & 7.55 & -1.62 & 1.71 & -0.95 & 1.61 & 0.20 \\
\hline $\mathrm{sc}$ & $-0.31^{* * *}$ & 0.07 & -4.50 & -0.66 & 1.05 & -0.63 & 0.12 & 0.73 \\
\hline co & $-0.89^{* * *}$ & 0.12 & -7.35 & 1.85 & 2.07 & 0.90 & 1.76 & 0.18 \\
\hline lo & $0.69^{* * *}$ & 0.13 & 5.34 & 2.41 & 4.15 & 0.58 & 0.17 & 0.68 \\
\hline $\mathrm{da}$ & $1.24^{* * *}$ & 0.13 & 9.72 & 0.67 & 1.94 & 0.35 & 0.09 & 0.77 \\
\hline $\operatorname{mip}$ & -0.03 & 0.04 & -0.89 & 0.03 & 1.08 & 0.03 & 0.00 & 0.95 \\
\hline & & & & & \multicolumn{2}{|c|}{ Joint Hausman test: } & 12.45 & 0.13 \\
\hline \multicolumn{7}{|c|}{ Error Correction Coefficients } & & \\
\hline Phi & $-0.52^{* * *}$ & 0.11 & -4.57 & -0.93 & 0.30 & -3.16 & & \\
\hline
\end{tabular}

As a result of the Hausman test performed to test whether the variables were homogeneous in long term, long-term homogeneity was concluded to exist, and the effective and consistent Pooled Mean Group Estimator (PMG) was determined to be the optimal estimator in our second model under the null hypothesis. The negative coefficient of statistically significant error correction (phi) demonstrates that there is a long-term relationship between economic growth and the institutional variables and that the balance is re-converged even when it is deviated from.

The pooled mean group estimator results regarding the group of countries governed by a full democracy regime are presented in Table 6. According to the results related to the full democracy countries, statistically significant results are observed to have been found for all the variables except for military impact on politics. These results demonstrate that the other regime types including the flawed democracy regime have problems regarding democratic governance while the full democracy regime have very limited problems about democracy, social and economic variables encourage economic growth in long term in the countries that have a political culture supporting democracy, and these variables have high levels of practicability as political tools.

The most significant positive effects are produced by the variables of democratic accountability and law and order while the most significant negative effects are produced by the variable of corruption, which is thought to stem from the facts that the countries in this group are developed in terms of democratic governance and their government operation levels are satisfactory, and that these countries are from Europe or countries like Australia, Canada, and New Zealand where the social, cultural, and economic development levels are extremely high. 


\section{Conclusion and Recommendations}

In spite of the view that multilateralism should play an active role in escaping global turmoil caused by changes and developments resulting from globalization, multilateral institutions cannot fulfill their basic functions due to the policies of the countries trying to be a global power and in turn their inability to perceive the instability and global developments occurring within the global system. This necessitates that the aspects of multilateralism be reassessed within the framework of globalization with a view to escaping global turmoil.

Even though the policies adopted by the USA, which is regarded as the single global power, have an international impact, the reason why global instability cannot be eliminated is that the nations wanting to become a global power do not have the necessary social and cultural infrastructure in addition to a strong economic and political structure. This brings along the idea that the policies pursued by the countries that have a strong sociocultural infrastructure and consequently a strong democracy will be effective in escaping global crisis and eliminating the instability created by global turmoil.

Based on this idea, the long-term institutional determinants of economic growth was analyzed with regard to political regime types in the study, and according to the results of this analysis, the socioeconomic variables in the full democracy regime group comprising of developed countries encourage economic growth. These results stem from the fact that the countries in this group have a developed social, cultural, and economic infrastructure. Indeed, in these countries which include some of the European ones, multilateral institutions and multilateralism, which are thought to play an important role in solving global problems in the future, are regarded as an effort to get together and a lifestyle rather than an issue of power or an international order, and this view endorses democratization and simplifies the solutions for problems.

The most effective way in escaping global crisis and turmoil is acknowledged to be the fact that countries should develop their socioeconomic infrastructures within the framework of their tendencies towards democratization due to the aforementioned reasons, and regulations should be performed to make the perception of multilateral institutions the same as that of the developed European countries which have the most democratic regime types. Indeed, reassessing multilateral institutions which are unable to find a solution for today's global issues by introducing a social dimension to economic tendencies within the framework of recent global changes, bringing ethic assessments and world democracy into the forefront, adopting policies that can eliminate regional inequalities, and also multilateral institutions' performing meetings open to developing or underdeveloped countries' participation are all estimated to be effective in eliminating the shortcomings of multilateral institutions and putting an end to the instability created by global turmoil in the future. 


\section{References}

Acemoglu, Daron and James A. Robinson. (2006). Economic Origins of Dictatorship And Democracy (USA: Cambridge University Press).

Acemoglu, Daron, Simon Johnson and James A. Robinson. (2001). The Colonial Origins of Comparative Development: An Empirical Investigation. American Economic Review 91(5): 1369-1401.

Acemoglu, Daron, Suresh Naidu, Pascual Restrepo, and James A. Robinson. (2019). Democracy Does Cause Growth. Journal of Political Economy 127 (1). The University of Chicago Press: 47-100.

Barro, Robert J. (1989). A Cross-Country Study of Growth, Saving, and Government. National Bureau of Economic Research Working Paper Series No. 2855.

Berg-Schlosser, Dirk. (1984). African Political Systems: Typology and Performance. Comparative Political Studies 17 (1): $121-$ 151.

Breusch, T. S. and A. R. Pagan. (1980). The Lagrange Multiplier Test and its Applications to Model Specification in Econometrics. The Review of Economic Studies 47 (1). [Oxford University Press, Review of Economic Studies, Ltd.]: 239-253.

Brzezinksi, Zbigniew. (1995). Out of Control: Global Turmoil on the Eve of the 21st Century. New York: Touchstone.

Dick, G William. (1974). Authoritarian versus Nonauthoritarian Approaches to Economic Development. Journal of Political Economy 82 (4). University of Chicago Press: 817-827.

ECOSOC. (2016). The Changing Political Economy of Globalization: Multilateral Institutions and the 2030 Agenda. New York: Joint Meeting of ECOSOC and The GA'S Second Committee, United Nations Headquarters, 1. Available at https:// www.un.org/ecosoc/sites/www.un.org.ecosoc/files/files/en/2016doc/2016-globalization-mtg-bcknote.pdf. Accessed 20 February 2019.

Gill, Stephen. (1997). Global Structural Change and Multilateralism. In Globalization, Democratization and Multilateralism, edited by Stephen Gill, 1-17. Tokyo-New York-Paris: United Nations University Press.

Gissinger, Ranveig, and Nels Petter Gleditsch. (1999). Globalization and Conflict: Welfare, Distribution, and Political Unrest. Journal of World-Systems Research 5(2): 327-365.

Glassman, Amanda. (2012). GHI 2013 and the Rise of Multilateralism | Center For Global Development. Available at $<$ https:// www.cgdev.org/blog/ghi-2013-and-rise-multilateralism>. Accessed 5 December 2018.

Grier, Kevin B, and Gordon Tullock. (1989). An Empirical Analysis of Cross-National Economic Growth, 1951-1980. Journal of Monetary Economics 24 (2): 259-276.

Groom, A. John R. (2006). Multilateralism as a Way of Life in Europe. In Multilateralism Under Challenge? Power, International Order and Structurel Change, edited by Edward Newman, Ramesh Chandra Thakur, John Tirman, 460-80. Tokyo-New York-Paris: United Nations University Press.

Hadri, Kaddour and Eiji Kurozumi. (2012). A Simple Panel Stationarity Test in the Presence of Serial Correlation and a Common Factor. Economics Letters 115 (1). North-Holland: 31-34.

Hausman, Jerry A. (1978). Specification Tests in Econometrics. Econometrica 46 (6). [Wiley, Econometric Society]: $1251-1271$.

Helliwell, J. F. (1992). Empirical Linkages Between Democracy and Economic Growth. National Bureau of Economic Research Working Paper Series. No. 4066. https://doi.org/10.3386/w4066

Hellsten, Sirkku K. (2006). Multilateralism and Economic Justice. In Multilateralism Under Challenge? Power, International 
Order and Structurel, edited by Edward Newman, Ramesh Thakur and John Tirman, 422-440. Tokyo-New York-Paris: United Nations University Press.

Huntington, Samuel. P. and Jorge I. Dominguez. (1975). Political Development. In Handbook of Political Science III, edited by Fred I. Greenstein and Nelson W. Polsby, 98-114. Reading, Mass.: Addison-Wesley.

Landau, Daniel. (1986). Government and Economic Growth in the Less Developed Countries: An Empirical Study for 1960-1980. Economic Development and Cultural Change 35 (1). University of Chicago Press: 35-75.

Lennon, Alexander T. J. and Amanda Kozlowski. (2008). Introduction: Concert or Clash of Global Powers in the 21st Century?. In Global Powers in the 21st Century: Strategies and Relations, edited by Alexander T. J. Lennon and Amanda Kozlowski, vii-xiii. Cambridge: MIT Press.

Jamali, Khurram, Kirsten Wandschneider, and Phanindra V Wunnava. (2007). The Effect of Political Regimes and Technology on Economic Growth. Applied Economics 39 (11). Routledge: 1425-1432.

Kay, Sean. (2004). Globalization, Power, and Security. Security Dialogue 35 (1): 9-25.

Mulligan, Casey B., Ricard Gil and Xavier Sala-i-Martin. (2004). Do Democracies Have Different Public Policies than Nondemocracies?. The Journal of Economic Perspectives 18(1): 51-74.

Newman, Edward and Ramesh Thakur. (2006). Conclusions: Multilateralism Under Challange or in Crisis?. In Multilateralism Under Challenge? Power, International Order and Structurel Change, edited by Edward Newman, Ramesh Chandra Thakur, John Tirman, 531-540. Tokyo-New York-Paris: United Nations University Press.

Newman, Edward, Ramesh Thakur and John Tirman. (2006). Introduction. In Multilateralism Under Challenge? Power, International Order and Structurel Change, edited by Edward Newman, Ramesh Chandra Thakur, John Tirman, 1-17. Tokyo-New York-Paris: United Nations University Press.

Newtimes.az, 24 April 2013, Global Chaos Threat.

Persson, Torsten and Guido Tabellini. (2007). The Growth Effect of Democracy: Is It Heterogenous and How Can It Be Estimated?. National Bureau of Economic Research Working Paper Series, No. 13150.

Pesaran, M. Hashem, Yongcheol Shin, and Ron P. Smith. (1999). Pooled Mean Group Estimation of Dynamic Heterogeneous Panels. Journal of the American Statistical Association 94 (446). [American Statistical Association, Taylor \& Francis, Ltd.]: 621-634.

Pesaran, M. Hashem. (2004). General Diagnostic Tests for Cross Section Dependence in Panels. Cambridge Working Papers in Economics 0435, Faculty of Economics, University of Cambridge.

Pesaran, M. H. and Takashi Yamagata. (2008). Testing Slope Homogeneity in Large Panels. Journal of Econometrics 142 (1): $50-$ 93.

Pesaran, M H, Aman Ullah, and Takashi Yamagata. (2008). A bias-adjusted LM test of error cross-section independence. The Econometrics Journal 11 (1). John Wiley \& Sons, Ltd (10.1111): 105-127.

Political Risk Services-International Country Risk Guide Methodology (PRS-ICRG). (2014). Available at https://www.prsgroup. com/wp-content/uploads/2014/08/prsmethodology.pdf.

Przeworski, Adam. (1966). Party System and Economic Development (Evanston, Ill: Northwestern University, 1966).

Remmer, Karen L. (1990). Democracy and Economic Crisis: The Latin American Experience. World Politics 42 (3). Cambridge University Press: 315-335. 
Rodrik, Dani, Arvind Subramanian, and Francesco Trebbi. (2004). Institutions Rule: The Primacy of Institutions Over Geography and Integration in Economic Development. Journal of Economic Growth 9 (2): 131-165.

Ruggie, John Gerard. (1992). Multilateralism: the Anatomy of an Institution. International Organization 46 (3). [MIT Press, University of Wisconsin Press, Cambridge University Press, International Organization Foundation]: 561-598.

Saenz, Tanya. (2016). Multilateral Institutions. Available at http://www.geni.org/globalenergy/library/organizations/index. shtml\#asia. Accessed 25 February 2019.

Stiglitz, Joseph Eugene. (2010). The Stiglitz Report: Reforming The International Monetary and Financial Systems in the Wake of the Global Crisis (New York-Londan: The New Press, 2010).

Sloan, John, and Kent L Tedin. (1987). The Consequences of Regime Type for Public-Policy Outputs. Comparative Political Studies 20 (1): 98-124.

Telò, Mario. (2013). Introduction. In Globalisation, Multilateralism, Europe: Towards A Better Global Governence?, edited by Mario Telò. Taylor \& Francis Ltd., Burlington, VT : Ashgate Publishing, London.

The Economist Intelligence Unit, (2018). Democracy Index 2017: Free Speech Under Attack. Available at https://cisp.cachefly.net/ assets/articles/attachments/72810_democracy_index_2017.pdf. Accessed 20 December 2018.

The Wilson Center. (2007). Globalisation: A New Challenge for Multilateralism. Available at https://www.wilsoncenter.org/article/ globalisation-new-challenge-for-multilateralism. Accessed 12 October 2018.

Westerlund, Joakim. (2008). Panel Cointegration Tests of The Fisher Effect. Journal of Applied Econometrics 23 (2): $193-233$. 